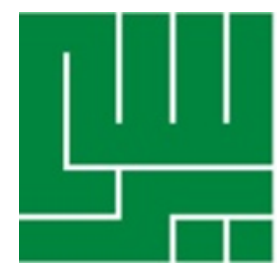

KATA KUNCI

KEYWORDS

ABSTRAK

ABSTRACT

\section{PEMAKNAAN PASIEN TERHADAP KOMUNIKASI PELAYANAN KESEHATAN DOKTER YANG BERTUGAS DI KLINIK DAN PUSKESMAS}

\author{
Riselligia Caninsti, Rahmi Nur Hidayati, \\ Alabanyo Brebahama, Endang Fourianalistyawati \\ Fakultas Psikologi Universitas YARSI \\ Jl. Letjen Suprapto, Cempaka Putih. Jakarta Pusat. 10510 \\ riselligia.caninsti@yarsi.ac.id; rahminuhi@gmail.com
}

komunikasi pelayanan kesehatan, dokter, klinik, puskesmas

communication of health service, doctor, clinic, primary health care

Penelitian ini dilatarbelakangi oleh fenomena sering terjadinya kesalahpahaman dalam hal komunikasi antara petugas kesehatan, yaitu dokter dengan pasien dan keluarga pasien di berbagai seting, seperti Rumah Sakit, Puskesmas, Klinik atau praktik pribadi. Pada penelitian ini, peneliti mencoba memahami pemaknaan pasien terhadap komunikasi pelayanan kesehatan dokter di fasilitas kesehatan primer yaitu klinik swasta dan Puskesmas. Tujuan penelitian ini yaitu memahami pengalaman pasien dan pemaknaannya terhadap komunikasi pelayanan kesehatan yang dilakukan oleh Dokter. Subjek penelitian berjumlah 6 orang, dengan 3 subjek merupakan pasien klinik dan 3 subjek adalah pasien Puskesmas. Penelitian ini menggunakan metode kualitatif fenomenologi, dengan metode pengumpulan data berupa wawancara dan observasi. Hasil penelitian menunjukan bahwa terdapat perbedaan pemaknaan terhadap komunikasi pelayanan kesehatan yang dilakukan oleh Dokter pada pasien klinik dan pasien Puskesmas. Perbedaan pemaknaan dalam komunikasi pelayanan kesehatan ini dilihat dari sisi proses komunikasi, unsur-unsur dalam komunikasi dan komunikasi efektif. Ada beberapa faktor yang memengaruhi persepsi pasien klinik dan Puskesmas terhadap komunikasi dokter. Pada pasien klinik, faktor yang memengaruhi persepsi pasien adalah si pemersepsi (orang yang melakukan persepsi, yang dalam hal ini adalah individu pasien). Sedangkan, pada pasien Puskesmas, persepsi komunikasi pasien lebih dipengaruhi oleh faktor target atau tujuan yang ingin dicapai ketika melakukan komunikasi dengan dokter di Puskesmas.

This research is trying to understand the meaning phenomenon of patients to the communication of physician health service in the primary health facility that is the private clinic and public health center (Puskesmas). The purpose of this study is to understand the essence of patient experience and its meaning to the communication of health services performed by the Doctor. Research subjects were six people, with three participants were clinical patients, and three participants were Puskesmas patients. This study uses the qualitative method of phenomenology, with data collection method in the form of interview and observation. The result of the research shows that there is a difference of meaning in clinic patient and Puskesmas patient related to doctor health service communication that seen from communication 
process, communication elements and the effectiveness of communication. There are several factors that influence the perception of clinic patient and Puskesmas towards doctor communication. In clinical patients, the factor that affects the perception of the patient is the perception (the person performing the judgment, which in this case is the individual patient). Whereas, in Puskesmas, patient communication perception is more influenced by target factor or goal to be achieved when doing communication with the doctor at Puskesmas.

\section{PENDAHULUAN}

\section{Latar belakang}

Setiap manusia pernah merasakan sakit, baik sakit fisik maupun psikologis. Orang sakit umumnya mengambil keputusan untuk upaya penyembuhan keluhan sakitnya. Upaya penyembuhan tersebut mencakup 3 hal pokok, yaitu; sumber pengobatan yang mampu mengobati keluhannya, kriteria yang digunakan untuk memilih sumber pengobatannya dan proses pengambilan keputusan untuk memilih sumber pengobatan tersebut. Sumber pengobatan mencakup 3 sektor yang saling berhubungan, yaitu: pengobatan sendiri, pengobatan tradisional dan pengobatan profesional (Young \& Kalangie dalam Supardi, Muktiningsih \& Handayani, 1997).

Menurut Rose (2001), orang yang melakukan pengobatan disebut pasien. Dalam Undang-Undang Republik Indonesia Nomor 29 Tahun 2004 tentang Praktik Kedokteran mengatakan bahwa pasien adalah orang yang melakukan konsultasi terkait masalah kesehatannya untuk memperoleh pelayanan kesehatan yang diperlukan baik secara langsung maupun tidak langsung kepada dokter atau dokter gigi (UU no. 29 tahun 2004 tentang Praktik Kedokteran ). Pada umumnya, jika menderita sakit, pasien dapat mendatangi fasilitas kesehatan seperti; rumah sakit, puskesmas, klinik, atau tempat-tempat lain yang dianggap dan diyakini mampu membuatnya menjadi sehat.

Di Indonesia, masyarakat yang ingin memperoleh pelayanan kesehatan banyak bergantung pada fasilitas kesehatan sektor swasta dan fasilitas kesehatan pemerintah, seperti ketika bersalin (kelahiran), anak menderita diare maupun infeksi pernafasan yang akut. Kecenderungan berobat ke fasilitas kesehatan tersebut terlihat semakin meningkat, sehingga upaya untuk meningkatkan pelayanan kesehatan perlu dilakukan guna membantu memberikan kontribusi bagi peningkatan kondisi kesehatan masyarakat (Erpan, Trisnantoro, \& Tudiono, 2012).

Pada kenyataannya, saat ini masih terdapat beberapa fasilitas kesehatan yang terjerat dalam masalah hukum, contohnya kasus yang terjadi di klinik swasta pada tahun 2014, yang mana saat itu Kepolisian Resor Jakarta Barat menangkap LRD (tersangka), berusia 67 tahun, yang merupakan pemilik Klinik Pratama Metropole, Tamansari, Jakarta Barat. Penangkapan itu terkait dengan kasus malpraktek yang diduga terjadi di Klinik Metropole. Klinik tersebut diduga melakukan praktek medik ilegal, sehingga mencuat testimoni pasien tentang bagaimana pasien merasa dirugikan akibat praktek pengobatan di klinik tersebut. Akhirnya pada September 2014, Sudin Kesehatan Jakarta Barat mencabut izin operasi pada klinik tersebut (Hartawan, 2014). Tidak hanya itu, terdapat juga kasus vaksin palsu yang beredar di klinik daerah Jakarta, yang mana dokter dan pemilik klinik merupakan tersangka dari kasus tersebut (Alvionitasari, 2016).

Kasus-kasus di klinik tersebut menimbulkan adanya dugaan malpraktek yang dilakukan oleh dokter dan mencerminkan masih buruknya komunikasi antara dokter dengan pasien di Indonseia (Widiyani, 2013). Di sisi lain, tidak semua klinik beroperasi dengan 
illegal atau melakukan tindakan malpraktik lainnya, karena pada kenyataannya banyak masyarakat yang masih memilih klinik sebagai tempat berobat. Di Kota Batam, Kepulauan Riau, terdapat 2.000 peserta Badan Penyelenggara Jaminan Sosial (BPJS) Kesehatan yang beramai-ramai mutasi dari pasien Puskesmas menjadi pasien klinik swasta, karena tidak puas dengan pelayanan Puskesmas (Rusdianto, 2016). Hal ini dikarenakan pelayanan klinik lebih lengkap daripada Puskesmas. Penuturan salah seorang pasien peserta BPJS juga menggambarkan bahwa petugas kesehatan di Puskesmas terkesan meremehkan pasien dengan cara menunda pemberian pelayanan, padahal menurut pasien, jumlah karyawan Puskesmas cukup banyak, namun karyawan tidak memperhatikan pasien dan pasien seringkali dibuat menunggu lama untuk mendapatkan pelayanan kesehatan. Di Daerah Istimewa Aceh terdapat kasus miskomunikasi antara dokter puskesmas dengan pasien, yang mana salah seorang dokter dilempar oleh pasien dengan menggunakan jagung rebus. Pasien merasa marah karena menurutnya dokter tersebut mengeluarkan kata-kata yang menyinggung perasaan pasien dan keluarganya (Bakri, 2015). Berdasarkan kondisi tersebut, dapat dikatakan bahwa tidak hanya klinik saja yang memiliki masalah antara tenaga medis dengan pasiennya, masalah-masalah tersebut juga ada di Puskesmas.

Penelitian Dewi (2009) menunjukan bahwa terdapat hubungan tingkat kepuasan pasien di Puskesmas dengan komunikasi dokter pasien. Ada beberapa faktor yang mempengaruhi proses komunikasi, seperti greeting (salam), non verbal, empati, bahasa, mendengarkan, memberi informasi, kesimpulan dan motivasi. Dari faktor-faktor tersebut, yang memiliki korelasi paling tinggi dengan kepuasan pasien adalah sikap empati dokter kepada pasien, dan faktor yang memiliki korelasi paling rendah dengan kepuasan pasien adalah greeting (salam). Padahal greeting (salam) merupakan salah satu keterampilan dasar yang harus dimiliki dokter untuk dapat membangun hubungan efektif sesuai norma budaya yang berlaku, greeting juga merupakan awal untuk mengajak pasien berpartisipasi dalam sebuah proses komunikasi.

Terkait pengaduan masalah komunikasi dokter di Indonesia, Surat Kabar Kompas (2013) merilis bahwa MKDKI menerima 186 pengaduan selama 2006-2013, yang mana masalah komunikasi dokter merupakan urutan ketiga setelah standar pelayanan dan kompetensi dokter. Dokter yang paling banyak diadukan yaitu dokter umum sebesar 50\% (Rmol, 2011). Wigati (2008) menjelaskan bahwa dokter memberi pengaruh dalam menentukan kualitas pelayanan kesehatan kepada pasien rawat jalan karena pada dasarnya pasien mencari pelayanan rawat jalan untuk mendapatkan konsultasi dokter yang disertai dengan tindakan pengobatan maupun tidak. Namun kenyataanya, hubungan antara dokter dengan pasien dalam rangka pelayanan kesehatan tidak berjalan dengan baik sehingga dapat memunculkan persepsi pasien yang kurang baik terhadap kualitas pelayanan kesehatan oleh dokter. Penilaian terhadap kualitas pelayanan kesehatan oleh pasien kepada dokter dinilai dari beberapa hal, seperti: waktu tunggu untuk melayani pasien, penjelasan yang tepat dan jelas terhadap keluhan akan penyakit yang dikatakan oleh pasien, ketanggapan dokter saat memberikan pelayanan kesehatan, kemampuan diagnosis dan pengetahuan dokter akan masalah kesehatan yang dialami pasien serta penanganannya lebih lanjut (Sari, 2013).

Menurut Kotler (dalam Amin \& Supratman, 2008) mutu atau kualitas suatu produk dapat diukur, namun dalam aspek pelayanan kesehatan, pengukuran mutu pelayanan sulit untuk dilakukan. Hal ini disebabkan karena umumnya kualitas pelayanan kesehatan bersifat subjektif, karena menyangkut kepuasan seseorang, bergantung pada persepsi, latar belakang 
sosial ekonomi, norma, pendidikan, budaya, bahkan kepribadian orang yang menilai. Penelitian terkait dengan persepsi pasien terhadap dokter di rumah sakit dari Wigati (2008), menunjukan bahwa pasien mempersepsi keterampilan teknis medis dokter kurang baik (50.9\%), pasien mempersepsi sikap dokter kurang baik (49.1\%), persepsi pasien terhadap penyampaian informasi dokter kurang baik (53.6\%), persepsi pasien terhadap ketepatan waktu pelayanan dokter kurang baik $(59.1 \%)$, persepsi pasien terhadap ketersediaan waktu konsultasi dokter kurang baik (52.7\%). Dengan adanya persepsi pasien yang kurang baik terhadap pelayanan kesehatan yang diberikan oleh dokter menyebabkan pasien menjadi kurang loyal dan frekuensi pasien untuk datang berobat kembali ke dokter tersebut menjadi berkurang. Selain itu, Green (dalam Notoatmojo, 2007) menjelaskan bahwa persepsi pasien juga merupakan faktor predisposisi yang mempengaruhi perilaku kesehatan pada diri pasien. Faktor lainnya yang menjadi penguat yaitu sikap dan perilaku petugas kesehatan dalam menangani pasien. Sikap dan perilaku petugas kesehatan juga mempengaruhi perilaku sehat pada pasien.

Data penelitian di atas memaparkan bahwa tenaga medis seperti dokter yang bertugas di rumah sakit tidak selalu memberikan kualitas pelayanan terbaik kepada pasiennya, karena adanya faktorfaktor yang menjadikan kurangnya kualitas pelayanan yang diberikan kepada pasien, seperti: keterampilan teknis medis, layanan non medis, sikap dokter dan penyampaian informasi. Pasien akan menilai kualitas dokter dari berbagai aspek. Aspek penting yang harus dimiliki oleh dokter yaitu aspek keterampilan komunikasi dalam menangani pasiennya. Apabila dokter memiliki keterampilan komunikasi yang baik dan efektif dalam memberikan pelayanan kesehatan, hal tersebut dapat membuat pasien mempunyai sugesti bahwa ia akan sembuh (Sari, 2013).
Berdasarkan hasil analisis kebutuhan pelatihan yang dilakukan terhadap dokter, diperoleh fakta bahwa keterampilan komunikasi dokter di Indonesia masih rendah. Hal ini terlihat dari masih banyaknya keluhan pasien terkait keterampilan komunikasi dokter, serta tingginya tuntutan hukum terhadap dokter yang lebih disebabkan oleh kurangnya kemampuan komunikasi dokter. Bahkan, masih banyak pasien yang mencari pengobatan di luar negeri karena pasien merasa tidak puas dengan pelayanan yang diberikan oleh dokter, terutama dari aspek komunikasi (Basuki, 2010).

Berdasarkan kasus - kasus tersebut, Parasuraman dan Berry (1991) melihat adanya kesenjangan antara persepsi pasien dan persepsi penyedia jasa pelayanan kesehatan (dalam hal ini adalah dokter) yang mengakibatkan kegagalan penyampaian jasa yang berkualitas. Penyedia jasa pelayanan kesehatan tidak selalu memahami secara tepat apa yang diinginkan pasien. Kesenjangan tersebut dapat disebabkan penyedia jasa pelayanan kesehatan seperti dokter mempersepsi bahwa pelayanan yang diberikan sudah cukup baik. Namun, persepsi pasien malah sebaliknya. Kondisi ini menunjukkan eratnya hubungan antara dokter dengan pasien dalam membentuk persepsi pasien pada dokter yang memberikan pelayanan kesehatan dan komunikasi yang baik diantara keduanya.

\section{Masalah Penelitian}

Penelitian yang sudah ada pada umumnya melihat persepsi petugas kesehatan seperti dokter atau perawat terhadap pasien, sehingga penting bagi peneliti untuk melihat sudut pandang lainnya yakni dari perspektif pasien sebagai pengguna jasa layanan. Pasien merupakan bagian terpenting dari proses komunikasi pelayanan kesehatan yang dapat merasakan dan memaknai pengalamannya mengenai komunikasi pelayanan kesehatan yang diberikan oleh petugas kesehatan, khususnya dokter. 
Penelitian tentang komunikasi pelayanan kesehatan terkait pemaknaan pasien terhadap komunikasi pelayanan kesehatan dokter di Indonesia jarang dilakukan, dan meskipun ada, setting yang digunakan seringkali adalah rumah sakit. Dari hal tersebut, penting bagi peneliti untuk melihat setting lain salah satunya yaitu klinik dan Puskesmas, karena saat ini pintu awal pasien berobat dan mendapatkan pelayanan kesehatan adalah klinik dan Puskesmas. Klinik dan Puskesmas juga memiliki lokasi yang umumnya mudah dijangkau pasien. Berdasarkan hal tersebut, peneliti merancang penelitian untuk memahami pemaknaan pasien terhadap pengalamannya terkait komunikasi pelayanan kesehatan yang dilakukan oleh dokter, baik dokter yang bertugas di klinik atau dokter yang bertugas di Puskesmas.

\section{Komunikasi dalam Pelayanan Kesehatan}

Komunikasi pelayanan kesehatan seringkali dikaitkan dengan komunikasi yang terjadi antara petugas pemberi layanan kesehatan (seperti: dokter, perawat, bidan, apoteker, dan petugas kesehatan lainnya) dengan pasien dan keluarga pasien. Beberapa ahli juga ada yang mengatakan bahwa komunikasi pelayanan kesehatan terjadi antara petugas pemberi layanan kesehatan, dan antara petugas pemberi layanan kesehatan dengan pasien atau keluarga pasien. Intinya, komunikasi pelayanan kesehatan adalah proses interaksi antara dua pihak untuk memperoleh informasi, memberikan informasi dan memberikan dukungan, yang dilakukan dalam setting kesehatan (Stewart \& Cash, 2006).

Menurut Northouse dalam (Basuki, 2010), ada beberapa unsur yang mempengaruhi komunikasi kesehatan antara petugas kesehatan dengan pasien, yaitu:

1. Empathy, dokter berusaha untuk memahami cara pandang pasien,yang mana dokter berusaha merasakan apa yang sedang dialami oleh pasien.
2. Control, dokter mampu mengontrol jalannya komunikasi dengan pasien

3. Trust, dokter dapat membangun rasa saling percaya dengan pasien.

4. Self-Disclosure, dokter mengungkapkan dirinya terkait fakta diri kepada pasien.

5. Confirmation, dokter menanyakan kembali apakah pesan yang disampaikan sudah dimengerti oleh pasiennya.

Sementara itu, menurut Government (2010), terdapat 5 standar komunikasi kesehatan yang efektif, yaitu:

1. Complete: Dokter selaku pemberi layanan kesehatan menjawab semua pertanyaan yang diajukan pasien ke tingkat yang memuaskan untuk pasien yang terlibat dalam pertukaran informasi.

2. Concise: Ekspresi bertele-tele diperpendek atau dihilangkan. Dokter memberikan laporan yang relevan dan menghindari pengulangan yang tidak perlu.

3. Concrete: Kata-kata yang digunakan oleh dokter mengandung arti, apa yang dikatakan spesifik dan dipertimbangkan. Dokter menyampaikan fakta yang akurat terkait informasi kata dan angka yang diberikan.

4. Clear: Singkat, akrab, kata percakapan antara dokter-pasien digunakan untuk membangun pesan yang efektif dan dimengerti.

5. Accurate: Tingkat bahasa sangat tepat ; jargon ambigu dihindari, seperti dokter tidak menggunakan ungkapan diskriminatif atau merendahkan kepada pasiennya.

Dalam komunikasi kesehatan antara dokter-pasien, terdapat beberapa standar yang harus dipenuhi agar proses komunikasi dapat dikatakan efektif, yaitu: dokter selaku pemberi layanan kesehatan perlu menjawab semua pertanyaan yang diberikan pasien mengenai keluhan yang diderita pasien (Complete), ekspresi dan pesan yang diberikan oleh dokter harus 
relevan dengan keluhan pasien (Concise), kata-kata yang diberikan oleh dokter memiliki makna dan fakta yang terkait dengan pasien (Concrete), percakapan antara dokter-pasien haruslah singkat dan jelas agar pesan yang disampaikan dapat dipahami oleh pasien (Clear). Dalam komunikasi kesehatan yang efektif, dokter juga perlu menghindari penggunaan bahasa yang sulit dipahami oleh pasien seperti bahasa ilmiah kedokteran, bahasa yang merendahkan pasien, dll. Lima unsur tersebut diperlukan oleh dokter untuk membentuk komunikasi kesehatan yang efektif kepada pasiennya.

\section{Tujuan Penelitian}

Tujuan penelitian ini adalah:

1. Mengetahui pengalaman pasien terhadap komunikasi pelayanan kesehatan yang diberikan oleh dokter yang bertugas di klinik dan Puskesmas.

2. Memahami pemaknaan pasien terhadap pengalamannya terkait komunikasi pelayanan kesehatan yang diberikan oleh dokter yang bertugas di klinik dan Puskesmas.

\section{Manfaat Penelitian}

Manfaat penelitian ini adalah:

\section{Manfaat Teoritis}

a. Sebagai sumbangan pemikiran bagi pengembangan disiplin ilmu Psikologi dalam komunikasi pelayanan kesehatan dan juga ilmu kodekteran dalam hal komunikasi yang baik dan efektif terhadap pasien.

b. Menambah pengetahuan mengenai persepsi pasien terhadap komunikasi pelayanan kesehatan oleh dokter yang berugas di klinik dan Puskesmas.

\section{Manfaat Praktis}

a. Bagi Peneliti

Peneliti dapat mengetahui dan memperoleh informasi yang lebih jelas mengenai kondisi pasien dan tanggapan pasien terkait pelayanan kesehatan yang telah diterimanya, sehingga dapat menambah wawasan penelitian. Disisi lain peneliti juga dapat mengetahui kualitas dari praktisi kesehatan yaitu dokter yang memberikan pelayanan kesehatan.

b. Bagi Pasien

$\begin{array}{lr}\text { Pasien dapat menyampaikan } \\ \text { pendapat/tanggapannya } & \text { mengenai } \\ \text { pelayanan kesehatan } & \text { yang telah } \\ \text { diterima. } & \end{array}$

c. Bagi Dokter dan pengelola klinik dan Puskesmas

Dokter dapat mengetahui dan memperoleh informasi penting berupa persepsi pasien, tanggapan dan dampak pelayanan kesehatan yang telah diberikannya, sebagai dasar untuk mengobati pasien atau menentukan bentuk pelayanan yang tepat bagi pasien sehingga fasilitas pelayanan kesehatan seperti klinik dan puskesmas dapat lebih meningkatkan kualitas pelayanan kesesehatannya dalam hal komunikasi pelayanan kesehatan.

d. Bagi para peneliti selanjutnya

Penelitian ini dapat digunakan sebagai referensi untuk melakukan penelitian pada bidang yang ada kaitannya dengan persepsi pasien terhadap komunikasi pelayanan kesehatan oleh dokter.

\section{METODE PENELITIAN}

\section{Jenis Penelitian}

Penelitian ini menggunakan pendekatan kualitatif. Penelitian kualitatif dapat digunakan jika Peneliti membutuhkan gambaran secara menyeluruh dan mendalam dari sudut pandang partisipan yang diteliti (Santoso \& Royanto, 2009).

Metode penelitian ini dipilih untuk mengungkapkan pemaknaan pasien terhadap komunikasi pelayanan kesehatan. Oleh sebab itu, penelitian kualitatif dipandang sesuai untuk menyelidiki dinamika pengalaman, perasaan dan pemaknaan dari sudut pandang pasien secara mendalam terhadap komunikasi pelayanan kesehatan yang diberikan oleh dokter yang bertugas di klinik dan Puskesmas di daerah Jakarta. 


\section{Rancangan Penelitian}

Penelitian ini menggunakan tipe penelitian fenomenologi. Penelitian fenomenologi bertujuan untuk memfokuskan pada esensi maupun makna yang terkandung dalam pengalaman hidup individu mengenai suatu fenomena atau peristiwa dalam kehidupannya (Hasbiansyah, 2008). Dalam penelitian ini, peneliti ingin memahami bagaimana pasien memaknai komunikasi pelayanan kesehatan yang diberikan oleh dokter. Pasien merupakan penilai dan pengguna terpenting dari suatu komunikasi pelayanan kesehatan, sehingga sudut pandang pasien terkait komunikasi pelayanan kesehatan menjadi data penelitian yang berharga.

\section{Cara penetapan dan besar sampel}

Menurut Poerwandari (2013), penelitian kualitatif cenderung terbuka dalam desain dan metodenya, sehingga metode pengambilan data dari subjek dapat diubah dan disesuaikan dengan konteks dan setting saat penelitian berlangsung. Sehingga, dalam penelitian ini, jumlah responden tidak ditentukan di awal, namun berdasarkan saturasi data. Saturasi adalah prinsip dalam mengumpulkan data dari responden yang mana informasi dikumpulkan sampai berada pada titik jenuh, yaitu ketika tidak diperoleh lagi informasi yang baru. (Poerwandari, 2013)

Penelitian ini menggunakan teknik pengambilan sampel accidental sampling, yaitu teknik penentuan responden berdasarkan kebetulan, yaitu sumber data dapat diperoleh dari siapa saja yang secara kebetulan bertemu dengan peneliti. Teknik ini digunakan karena topik yang diteliti adalah mengenai komunikasi pelayanan kesehatan yang dimana semua orang dapat memberikan pemaknaannya terhadap komunikasi pelayanan kesehatan (Sugiyono, 2010)

\section{Jenis data}

Jenis data yang diperoleh adalah data kualitatif / deskriptif mengenai pemaknaan pasien terhadap komunikasi pelayanan kesehatan yang dilakukan oleh dokter yang bertugas di klinik dan Puskesmas.

\section{Metode dan Instrumen pengumpulan data Observasi Partisipatif}

Metode pengumpulan data dengan cara terjun langsung dan diarahkan pada kegiatan memperhatikan secara akurat, mencatat fenomena atau kejadian yang mucul dan mempertimbangkan hubungan antar aspek fenomena tersebut (Poerwandari, 2013). Meski demikian, dalam penelitian ini, peneliti menemukan sejumlah hambatan untuk melakukan observasi partisipatif seperti masalah perizinan. Oleh sebab itu, dalam penelitian ini peneliti hanya menggunakan observasi secara umum atau non partisipatif.

Wawancara Terbuka

Peneliti menggunakan teknik wawancara sehingga instrumen yang digunakan berupa pedoman wawancara dan panduan observasi yang sudah dibuat sebelumnya. Wawancara berfokus pada isu-isu yang harus diperdalam tanpa menentukan urutan pertanyaan. Isi wawancara dapat mengarahkan pembicaraan pada aspek-aspek tertentu dari pengalaman subjek.

\section{Alat Bantu Penelitian}

Pada penelitian ini, peneliti menggunakan alat bantu berupa voice recorder untuk merekam hal-hal yang dikemukakan oleh partisispan, sehingga dapat memudahkan peneliti untuk mengulang kembali hasil wawancara yang dilakukan dan meminimalisir hilangnya informasi dari partisipan.

\section{Analisis data}

Menurut Royanto \& Santoso (2009), analsis data penelitian kualitatif dapat dilakukan dengan 2 tahap, yaitu: analisis intra-subjek dan analisis inter-subjek. Pada tahap analisis intra-subjek, peneliti menguraikan gambaran setiap partisipan dengan rinci. Setelah itu dilanjutkan 
dengan uraian temuan penelitian dengan menggunakan cara membaca data secara faktual, interpretif dan reflektif. Setelah analisis intra-subjek, dilanjutkan dengan analisis inter-subjek. Pada tahap analisis inter-subjek, peneliti menggunakan teknik analisis Segmenting, yaitu data dari transkrip diambil satu bagian tertentu, kemudian bagian tersebut diinterpretasikan sesuai dengan teori atau konsep yang telah dikemukakan sebelumnya. Selanjutnya dari data yang diperoleh, dibuat pengelompokan-pengelompokan dan dimasukan kedalam kategori-kategori yang telah ditentukan (Tesch, dalam Royanto \& Santoso, 2009).

\section{Kredibilitas Penelitian}

Menurut Poerwandari (2013), dalam penelitian kualitatif, untuk dapat menilai kelengkapan dan 'kebenaran' data yang telah dikumpulkan dan juga menilai bahwa penelitian ini sudah mencapai tujuannya dalam mengeksplorasi masalah penelitian, adalah melalui kredibilitas. Kredibilitas dilakukan antara lain dengan cara:

1) Mencatat bebas hal-hal penting serinci mungkin mencakup pengamatan objektif terhadap partisipan.

2) Mendokumentasikan secara lengkap dan rapi data yang terkumpul, proses pengumpulan data maupun strategi analisisnya.

3) Memanfaatkan langkah-langkah dan proses yang diambil peneliti- peneliti sebelumnya sebagai masukan bagi peneliti untuk menjamin pengumpulan data yang berkualitas.

4) Menyertakan orang-orang yang dapat berperan sebagai pengkritik yang memberikan saran-saran dan pertanyaan kritis terhadap analisis yang dilakukan peneliti (anggota tim penelitian, mahasiswa pengumpul data).

\section{ANALISIS DAN HASIL}

Hasil yang dicapai dalam penelitian ini adalah:

\section{Analisis Pemaknaan Pasien Klinik terhadap Proses Komunikasi Pelayanan Kesehatan Dokter}

Dilihat dari hasil proses komunikasi, ketiga subjek dapat mengetahui dan memahami hal-hal yang menjadi bagian dari proses komunikasi. Subjek sebagai pasien klinik menginterpretasi bahwa dokter dan kasir merupakan pengirim pesan kesehatan. Dokter klinik dilihat sebagai orang yang melakukan tindakan medis dan kasir sebagai administrasi. Sebagai penerima pesan dari dokter, subjek dapat menjelaskan informasi yang diberikan dokter kepadanya dan merasa bahwa pesan yang disampaikan cukup baik dan bermanfaat dalam penyembuhan pasien, meskipun terdapat juga subjek yang kurang puas dengan informasi kesehatan yang diberikan dokter.

Tabel 1. Data Profil Subjek

\begin{tabular}{|c|c|c|c|c|c|c|}
\hline Data Umum & Subjek K1 & Subjek K2 & Subjek K3 & Subjek P1 & Subjek P2 & $\begin{array}{c}\text { Subjek } \\
\text { P3 } \\
\end{array}$ \\
\hline Nama (Inisial) & $\mathrm{F}$ & $\mathrm{N}$ & $\mathrm{W}$ & $\mathrm{R}$ & $\mathrm{K}$ & $\mathrm{S}$ \\
\hline Jenis Kelamin & $\mathrm{L}$ & $\mathrm{P}$ & $\mathrm{L}$ & $\mathrm{P}$ & $\mathrm{P}$ & $\mathrm{P}$ \\
\hline Usia & 20 tahun & 32 tahun & 44 tahun & 67 tahun & 63 tahun & 47 tahun \\
\hline $\begin{array}{l}\text { Tempat } \\
\text { Tinggal }\end{array}$ & Jakarta & Jakarta & Jakarta & Jakarta & Jakarta & Jakarta \\
\hline $\begin{array}{l}\text { Pendidikan } \\
\text { Terakhir }\end{array}$ & SMA & D3 & $\mathrm{S} 1$ & S1 & SD & $\mathrm{SD}$ \\
\hline Status & Lajang & Menikah & Menikah & Menikah & Menikah & Menikah \\
\hline Pekerjaan & Pegawai & $\begin{array}{c}\text { Karyawan } \\
\text { Swasta }\end{array}$ & $\begin{array}{c}\text { Karyawan } \\
\text { Swasta }\end{array}$ & Guru & ART & IRT \\
\hline $\begin{array}{l}\text { Diagnosis } \\
\text { Penyakit }\end{array}$ & Flu & Flu, Demam & Flu, Mual & $\begin{array}{c}\text { Batuk, } \\
\text { Pilek, } \\
\text { Sakit kaki }\end{array}$ & $\begin{array}{c}\text { Gula, } \\
\text { Asam Urat }\end{array}$ & $\begin{array}{l}\text { Kesemutan, } \\
\text { Asam Urat }\end{array}$ \\
\hline $\begin{array}{l}\text { Biaya } \\
\text { pengobatan }\end{array}$ & Sendiri & Sendiri & Sendiri & Askes & BPJS & BPJS \\
\hline
\end{tabular}


Keterangan:

K1 : Subjek Klinik 1

K2 : Subjek Klinik 2

K3 : Subjek Klinik 3

P1 : Subjek Puskesmas 1

P2 : Subjek Puskesmas 2

P3 : Subjek Puskesmas 3

Ditinjau dari proses komunikasi, hanya dua subjek yang melibatkan orang terdekatnya untuk mengikuti jalannya proses komunikasi dengan alasan-alasan yang berbeda. Dalam penerimaan respon dan feedback, subjek dapat mengartikan respon ataupun feedback yang mereka dapatkan dan mereka berikan kepada dokter. Namun, terdapat juga subjek yang merasakan respon ataupun feedback yang kurang menyenangkan dari dokter, karena feedback yang dokter berikan tidak sesuai dengan harapannya. Sehingga, bisa dikatakan bahwa dalam proses komunikasi, jika subjek merasa dokter sudah baik dalam proses komunikasi, maka subjek akan merasa tidak ada hambatan yang terjadi. Begitu pula sebaliknya, apabila dalam proses komunikasi subjek merasa dokter kurang baik dalam prosesnya, maka subjek merasa ada hambatan yang terjadi.

\section{Analisis Pemaknaan Pasien Klinik terhadap Unsur-Unsur Komunikasi Pelayanan Kesehatan Dokter}

Ditinjau dari hasil unsur-unsur komunikasi, subjek dapat menjelaskan apaapa saja yang mereka rasakan selama proses komunikasi berlangsung dan mereka merasa bahwa keluhan yang disampaikan kepada dokter sudah maksimal. Dalam hal empati, subjek klinik merasakan adanya empati yang dimiliki dokter seperti keluhannya dapat dipahami oleh dokter. Namun, terdapat juga subjek yang merasa dokter kurang dapat memahaminya dan juga kurang ingin mencari tahu dan menggali lebih dalam keluhan pasiennya. Subjek memaknai dokter ingin buru-buru menyelesaikan sesi konsultasi.

Pada aspek hubungan kepercayaan antara pasien dengan dokter, terdapat subjek yang percaya bahwa dokter dapat menyembuhkannya, namun itu juga merupakan perantara dari Allah karena sebenarnya Allah lah yang menyembuhkannya. Dalam hal mengeluarkan keluhannya, hanya satu subjek yang merasa kurang dapat mengutarakan isi hatinya karena ia tidak paham dengan halhal yang disampaikan dokter, sehingga dalam hal ini dokter perlu melakukan konfirmasi mengenai hal-hal apa saja yang belum terungkap dalam proses komunikasi.

\section{Analisis Pemaknaan Pasien Klinik terhadap Komunikasi Efektif Pelayanan Kesehatan Dokter \\ Ditinjau dari aspek komunikasi} efektif, terdapat 1 subjek yang merasa komunikasi dokter kurang efektif, hal ini dikarenakan dokter kurang dapat menjelaskannya secara menyeluruh mengenai kondisi dan penyakit pasien, sehingga subjek merasa kurang puas. Namun 2 subjek merasa komunikasi dokter cukup efektif dalam memberikan penjelasan.

Subjek / pasien merasa bahwa dokter semestinya tidak hanya sekedar menanyakan kondisi pasien kemudian langsung memberikan obat, namun, dokter seharusnya memiliki keingintahuan yang baik agar dapat menggali kondisi pasien lebih dalam. Jika hal tersebut dilakukan, maka pasien akan merasa puas dan tercipta rasa kasih sayang. Alasan subjek memilih untuk berobat ke klinik adalah atas dasar keinginannya sendiri, oleh sebab itu dokter sangat perlu memperhatikan proses komunikasi dengan pasien agar para pasien dapat merasakan kepuasan dalam pengobatannya. Dokter juga diharapkan dapat memahami hal-hal yang pasien inginkan.

Analisis Pemaknaan Pasien Puskesmas terhadap Proses Komunikasi Pelayanan Kesehatan Dokter

Dilihat dari aspek proses komunikasi, ketiga pasien puskesmas dapat mengetahui dan merasakan hal-hal yang 
menjadi bagian dari proses komunikasi. Dari ketiga subjek, semuanya mengetahui bahwa dokter dan perawat merupakan pengirim pesan kesehatan, ketiga pasien juga merasa puas akan komunikasi pelayanan kesehatan yang telah diberikannya.

Sebagai penerima pesan kesehatan dari dokter, semua subjek dapat menjelaskan apa-apa saja informasi yang diberikan dokter kepadanya. Lalu dalam melakukan prosesnya, hanya dua subjek yang melibatkan orang terdekatnya untuk mengikuti jalannya proses komunikasi dengan alasan-alasan yang berbeda. Dalam pemberian feedback, semua subjek dapat mengartikan feedback apa saja yang mereka dapatkan dan mereka berikan kepada dokter. Hanya satu subjek yang merasakan adanya hambatan yang terjadi dalam proses komunikasi, namun, hal tersebut bukan karena dokternya melainkan karena subjek P2 belum mendapatkan hasil rongent-nya, sehingga ia menjadi kurang dapat mengetahui lebih dalam terkait penyakitnya karena dokter tidak dapat menjelaskannya.

\section{Analisis Pemaknaan Pasien Puskesmas terhadap Unsur-Unsur Komunikasi Pelayanan Kesehatan Dokter}

Dilihat dari unsur-unsur komunikasi, ketiga subjek dapat memaknai hal-hal yang menjadi bagian dari unsur-unsur komunikasi. Subjek dapat merasakan empati yang diberikan dokter dalam memahami keluhannya. Terutama subjek P2 yang sudah mengenal dokter cukup lama. Empati dokter makin terasa hingga pasien berpikir bahwa dokter terlihat sedih akan kondisi subjek.

Ketiga subjek merasa bahwa arahan yang diberikan dokter sangat baik. Ketiga subjek juga merasa adanya kepercayaan yang terjalin antara dokter dengan pasien, sehingga pasien berpikir untuk kembali lagi dan memilih dokter tersebut jika akan berobat. Pada aspek self disclosure, subjek mengungkapkan keluhannya kepada dokter dengan sebenar-benarnya. Sementara itu saat mengakhiri sesi konsultasi, ketiga subjek menyampaikan bahwa dokter tidak melakukan konfirmasi ulang mengenai keluhan pasien. Menurut salah satu subjek, yaitu P2, hal tersebut disebabkan dokter sudah mengenal betul kondisi pasiennya.

\section{Analisis Pemaknaan Pasien Puskesmas terhadap Komunikasi Efektif Pelayanan Kesehatan Dokter}

Ditinjau dari aspek komunikasi efektif, ketiga subjek dapat memahami pesan yang disampaikan oleh dokter, dokter pun dinilai dapat memahami isi keluhan pasien, hal ini menimbulkan kesenganan pada diri pasien. Ketiga subjek dapat mengerti penjelasan yang disampaikan dokter, sehingga dapat mempengaruhi sikap subjek terhadap kesehatannya. Kondisi tersebut menjadikan ketiga subjek merasakan adanya hubungan sosial yang baik antara dokter dan pasien dalam proses komunikasinya, dan pasien memaknai dokter telah melakukan komunikasi secara efektif.

Berdasarkan uraian mengenai pemaknaan pasien terhadap komunikasi pelayanan kesehatan dokter di Puskesmas, dapat disimpulkan bahwa komunikasi yang terjalin antara dokter dan pasien berperan penting bagi pasien karena mereka dapat mengeluarkan keluhannya. Ketiga subjek mengetahui di Puskesmas, yang menjadi pengirim pesan utama yaitu dokter, sementara perawat hanya melakukan pemeriksaan / cek awal terhadap kesehatan pasien.

Pada saat melakukan proses komunikasi, subjek dapat menjelaskan bahwa dokter dapat memahami dirinya. Menurut salah satu subjek, yaitu subjek P2, hal tersebut dikarenakan pasien sudah mengenal dokter cukup lama dan selalu berobat kepadanya, sehingga dalam prosesnya subjek merasakan komunikasi tersebut sudah baik dan merasa dokter memiliki empati yang baik, maka komunikasinya pun dinilai efektif.

\section{DISKUSI}

Dilihat dari analisis yang telah dijabarkan sebelumnya, dapat ditarik kesimpulan bahwa komunikasi merupakan hal penting bagi pasien saat melakukan pengobatan kepada dokter. Rangkuman kedua uraian mengenai pemaknaan pasien klinik dan pasien Puskesmas terhadap 
komunikasi pelayanan kesehatan dokter, menunjukkan bahwa terdapat perbedaan pemaknaan terhadap 3 tema yang ditelusuri, yaitu dari sisi proses komunikasi, unsurunsur dalam komunikasi, serta komunikasi efektif.

Ditinjau dari proses komunikasi, pasien klinik dan Puskesmas sama-sama mengetahui bagaimana proses komunikasi, namun terdapat perbedaan dalam pemaknaan proses komunikasinya, yaitu dalam pengirim pesan. Di klinik, petugas kesehatan terdiri dari dua orang yaitu dokter dan kasir. Sedangkan di Puskesmas, pengirim pesan dilakukan oleh banyak pihak seperti dokter, perawat, kasir, dll. Hal tersebut menjadikan dokter di klinik sebagai sumber komunikasi pelayanan kesehatan yang utama, karena tenaga medis di klinik hanya dokter saja. Pasien klinik juga lebih menilai dan mengevaluasi bagaimana komunikasi dokter dalam memberikan pesan kesehatan kepadanya, sehingga apabila ada ketidaksesuaian antara harapan pasien dengan kenyataan yang ada dalam mendapatkan informasi kesehatan, maka pasien merasa kecewa dan tidak akan memilih untuk datang kembali ke dokter tersebut.

Menurut Budiarjo \& Irwiensyah (2008), pasien klinik merupakan pasiengenerative revenue yaitu pasien yang menggunakan biaya mandiri dan memilih sendiri dokter dokter yang dianggapnya bagus. Sedangkan pasien Puskesmas, merupakan pasien- Need Help yang pada dasarnya berobat bukan karena memilih keahlian dokternya, namun karena meenggunakan biaya gratis dari Asuransi Kesehatan (BPJS) dan sejenisnya. Sehingga, terlihat perbedaan pemaknaan dalam proses komunikasi. Pasien klinik lebih menilai dan mengevaluasi bagaimana sikap dokter terhadapnya dibandingkan dengan pasien Puskesmas yang lebih mementingkan pengobatan yang diperolehnya.

Analisis yang dilakukan pada unsurunsur komunikasi, diperoleh data bahwa pasien klinik merasa komunikasi pelayanan kesehatan di klinik sudah cukup baik, namun terdapat juga pasien yang merasa kecewa terhadap komunikasi dokter yang dinilai tidak sesuai dengan harapan pasien. Kekecewaanya tersebut dikarenakan dokter terkesan memberikan penanganan secara terburu-buru, padahal menurut pasien kondisi klinik dalam keadaan sepi, yang mana pada kondisi sepi ini dokter seharusnya lebih tenang dan santai dalam melakukan komunikasi pelayanan kesehatan kepada pasien. Dalam memaknai sikap dokter terhadapnya, pasien klinik juga kurang dapat menjelaskan lebih dalam mengenai sikap empati maupun rasa percaya yang timbul antara kedua belah pihak, hal tersebut dikarenakan pasien klinik tidak selalu menggunakan dokter yang sama setiap kali ia berobat.

Pada pasien Puskesmas, empati dan rasa percaya antara dokter dan pasien cukup jelas tergambar. hal tersebut dikarenakan pasien merasa dirinya dengan dokter telah mengenal cukup lama, yang mana setiap kali pasien berobat selalu di Puskesmas yang sama dengan dokter yang sama pula. Pada pasien Puskesmas, ditinjau dari unsur konfirmasi, pasien Puskesmas merasa bahwa dokter tidak melakukan konfirmasi saat mengakhiri konsultasi. Menurut pasien, hal tersebut dikarenakan proses konsultasi di Puskesmas cukup singkat dan banyaknya pasien lain yang menunggu untuk mendapatkan pengobatan.

Persepsi pasien dalam memaknai komunikasi pelayanan kesehatan yang dilakukan oleh dokter dapat dipengaruhi oleh beberapa faktor, antara lain: faktor pemersepsi (orang yang mempersepsi), faktor target dan faktor situasi (Robbins dalam Maulana \& Gumelar, 2013). Dari hasil analisis pada ketiga pasien klinik, terlihat bahwa faktor pemersepsi lebih dominan dalam membentuk persepsi pasien klinik. Pasien klinik merasa komunikasi dokter cukup baik karena pasien merasakan kepuasan atas sikap dokter yang menanganinya, dengan kata lain kenyataan yang diterima pasien dari pelayanan kesehatan yang dilakukan dokter sesuai dengan harapannya. Di sisi lain, terdapat juga pasien yang merasa kecewa terhadap komunikasi yang dilakukan oleh dokter, hal ini dikarenakan pada pengalaman sebelumnya pasien merasa dokter tidak dapat 
memahami keluhannya dengan baik, dengan kata lain harapan pasien kepada dokter tidak sesuai dengan kenyataan yang diterimanya.

Sementara itu, pada pasien Puskesmas, faktor yang dominan membentuk persepsi pasien terhadap komunikasi pelayanan kesehatan dokter adalah faktor target. Pasien Puskesmas menilai komunikasi pelayanan kesehatan dokter sudah baik karena pasien merasakan adanya kedekatan hubungan dengan dokter yang sering bertemu dengannya. Menurut Ariadi (2005), dengan melihat persepsi pasien terhadap komunikasi pelayanan kesehatan dokter, maka kita akan mengetahui bagaimana gambaran hubungan interpersonal antara pasien dan dokter, hal tersebut merupakan aspek penting dalam membentuk persepsi pasien. Pasien akan memberikan penilaian secara subjektif mengenai cara dokter berkomunikasi dengan efektif, seperti: apakah dokter memahami perasaan pasien dan memperhatikan pasien dalam mengeluarkan keluhannya? Adanya pemahaman yang diterima pasien dari komunikasinya dengan dokter akan memunculkan pemaknaan yang lebih dalam pada diri pasien.

Pada penelitian ini diperoleh hasil bahwa pemaknaan pasien terhadap komunikasi pelayanan kesehatan sangat bereperan penting dalam menciptakan komunikasi yang efektif, terutama dalam hal pengertian dan hubungan sosial yang baik antara keduanya. Adanya pemaknaan pasien pada komunikasi pelayanan kesehatan yang dilakukan oleh dokter diharapkan dapat menjadi perhatian bagi dokter untuk memperhatikan proses komunikasinya dengan pasien, unsur-unsur yang terdapat dalam komunikasi dan membangun komunikasi yang efektif kepada pasiennya. Adanya penerapan komunikasi pelayanan kesehatan yang baik oleh dokter membuat pasien memaknai komunikasi pelayanan kesehatan dengan baik pula. Begitu juga sebaliknya, apabila dokter menerapkan komunikasi pelayanan kesehatan yang buruk, maka pasien akan memberikan pemaknaan yang buruk pula terhadap komunikasi pelayanan kesehatan yang dilakukan oleh dokter.
Dapat disimpulkan bahwa penelitian ini dapat menggambarkan pemaknaan pasien secara lebih mendalam mengenai komunikasi pelayanan kesehatan oleh dokter. Namun, pada penelitian ini juga memiliki beberapa keterbatasan, yaitu: 1). Dalam menggunakan metode penelitian, peneliti tidak menggunakan observasi partisipatif untuk mengambil data. Peneliti hanya menggunakan observasi secara umum saja atau non partisipatif, hal tersebut dikarenakan berbagai faktor seperti sulitnya perizinan untuk melakukan observasi saat komunikasi pelayanan kesehatan berlangsung. Bagi peneliti selanjutnya yang akan meneliti tema yang sama, sebaiknya menggunakan observasi partisipatif guna melihat secara akurat proses komunikasi yang berlangsung antara dokter-pasien, baik dalam melihat komunikasi verbal maupun non-verbal dokter dan sikap pasien dalam mendapatkan informasi tersebut. 2). Dalam meningkatkan kredibilitas penelitian, peneliti kurang melakukan upaya yang sistematis seperti triangulasi data.

\section{SIMPULAN DAN SARAN}

Pada bab ini, diuraikan kesimpulan dan saran sehubungan dengan hasil yang diperoleh dari penelitian.

\section{Simpulan}

Berdasarkan hasil penelitian dan pembahasan dapat ditarik kesimpulan mengenai hasil penelitian sebagai berikut:

1. Terdapat perbedaan pemaknaan pada pasien klinik dan Puskesmas terkait dengan proses komunikasi, unsurunsur komunikasi dan komunikasi efektif.

2. Pemaknaan pasien terhadap komunikasi pelayanan kesehatan dokter di klinik lebih banyak mengarah pada bagaimana pasien mempersepsi pesan dan cara/ tindakan dokter saat mendengarkan keluhan pasien.

3. Persepsi pasien terhadap komunikasi pelayanan kesehatan dokter di Puskesmas lebih banyak mengarah pada bagaimana pasien mempersepsi sikap dokter pada saat konsultasi. 
4. Pada pasien klinik, faktor yang mempengaruhi persepsi pasien terhadap komunikasi pelayanan kesehatan dipengaruhi oleh karakteristik-karakteristik pribadi yaitu faktor pemersepsi, seperti harapan pasien kepada dokter, tujuan pasien dalam pengobatan, pengalaman dan pengharapan pasien. Sedangkan, pada pasien Puskesmas faktor persepsi lebih banyak dipengaruhi oleh karakteristik target itu sendiri, seperti kedekatan dokter dengan pasien.

\section{Saran}

Beberapa saran teoritis dan praktis untuk penelitian selanjutnya yang berhubungan dengan pemaknaan pasien terhadap komunikasi pelayanan kesehatan oleh dokter, antara lain:

1. Dalam penelitian selanjutnya, wawancara terhadap petugas kesehatan khususnya dokter bisa dilakukan. Hal tersebut berguna untuk meng-cross check jawaban dari pasien terkait jalannya proses komunikasi.

2. Oleh karena keterbatasan penelitian ini yaitu hanya menggunakan observasi umum, maka disarankan untuk penelitian selanjutnya menggunakan observasi partisipatif untuk melihat proses berlangsungnya komunikasi pelayanan kesehatan.

3. Dalam penelitian selanjutnya, terkait metode yang digunakan yaitu berupa wawancara, dapat lebih diperdalam agar tema-tema yang ada lebih bervariasi.

4. Bagi para dokter atau penyedia jasa layanan kesehatan khususnya yang berada di klinik atau Puskesmas, dapat menyediakan layanan berupa kotak surat sebagai wadah pasien mengemukakan saran dan masukannya mengenai pelayanan kesehatan, khususnya terkait komunikasi pelayanan kesehatan dokter.

\section{DAFTAR PUSTAKA}

\section{Sumber Buku}

Government, V. (2010). Promoting effective communication among healthcare professionals to improve patient safety and quality of care. Victoria: Department of Health.

King, LA. (2013). Psikologi umum sebuah pandangan apresiatif Buku 1 . Jakarta: Salemba Humanika.

Ling, J \& Catling, J. (2012). Psikologi kognitif. Jakarta: Erlangga

Maulana, H \& Gumelar, G. (2013). Psikologi komunikasi dan persuasi. Jakarta: Akademia Permata.

Moleong, L.J. (2000). Metode penelitian kualitatif. Bandung: Remaja Rosdakarya.

Notoatmojo, Soekidjo. (2007). Promosi kesehatan dan ilmu perilaku. Jakarta: Rineka Cipta.

Poerwandari, E.K. (2013). Pendekatan kualitatif untuk penelitian perilaku manusia. Depok: Lembaga Pengembangan Sarana Pengukuran dan Pendidikan Psikologi (LPSP3), UI.

Rakhmat, J. (2003). Psikologi Komunikasi (edisi revisi). Bandung: Remaja Rosda Karya

Santoso, G.A \& Royanto, L.R.M. (2009). Teknik penulisan laporan kualitatif. Depok: Lembaga Pengembangan Sarana Pengukuran dan Pendidikan Psikologi (LPSP3), UI.

Sarwono, SW. (2008). Berkenalan dengan tokoh aliran-aliran dan tokoh-tokoh psikologi. Jakarta: Bulan Bintang

Sugiyono. (2014). Cara mudah menyusun : Skripsi, tesis, dan disertasi. Bandung: Alfabeta.

Sobur, A. (2011). Psikologi uтиm. Bandung: Pustaka Setia.

Stewart, C.J.R., Cash.W.B. (2006). Interviewing: Principles and Practices. New York: Mc Graw Hill 


\section{Sumber Jurnal}

Arianto, A. 2013. Komunikasi Kesehatan: Komunikasi Antara Dokter dan Pasien. Jurnal Ilmu Komunikasi, 3, (2). 1-13.

Basuki, E.S.M. (2010). Komunikasi Petugas Kesehatan dengan Klien dalam pelayanan kedokteran di Indonesia. Pidato pada upacara pengukuhan sebgai Guru Besar Tetap. Fakultas Kedokteran Universitas Indonesia.

Budiardjo, E.K., Irwiensyah, F. (2008). Analisis Fitur CRM Untuk Meningkatkan Kepuasan Pasien Berbasis Pada Framework Of Dynamic CRM Studi Kasus: Departemen Obstetri dan Ginekologi FKUI - RSCM Jakarta", Seminar Nasional Informatika 2008 (semnasIF 2008), 1, (5), pp. 349-357

Dewi, A. (2009). Kepuasan Pasien Terhadap Komunikasi Dokter Pasien di Puskesmas. Mutiara Medika. 9. (2). 37-45.

Erpan, L. N., Trisnantoro, L., \& Tudiono. (2012). Koordinasi Pelaksanaan Pembiayaan Program Kesehatan Ibu Dan Anak Di Kabupaten Lombok Tengah Provinsi Nusa Tenggara Barat Tahun 2011. Jurnal Kebijakan Kesehatan Indonesia, 1, 42-51.

Hasbiansyah, O. (2008). Pendakatan Fenomenologi: Pengantar Praktik Penelitian dalam Ilmu Sosial dan Komunikasi. Mediator. 9. (1). 163180.

Parasuraman, A., Zeithml,VA., Berry, L.L. (1988). SERVQUAL: A Multipleitem

Scale for Measuring Consumer Perceptions of Service Quality. Journal of Retailing, 64, (1), 12-41.

Rose, G. (2001). Sick Individual and Sick Pouplation. International Journal of Epidemiology, 30, 427-432.

Supardi, S. Muktiningsih, S.R. Handayani, R.S. (1997). Faktor-Faktor Yang Mempengaruhi Pemilihan Obat Atau Obat Tradisional Dalam Upaya
Pengobatan Sendiri Di Pedesaan. Buletin Penelitian Kesehatan. 25 (3\&4), 26-33.

\section{Sumber Lain}

Alvionitasari, R. (2016). Kasus Vaksin Palsu, Polisi Periksa Dokter di Klinik Palmerah. Diakses pada Maret 2017, dari https://m.tempo.co/read/news/2016/0 7/17/063788163/kasus-vaksinpalsupolisi-periksa-dokter-di-klinikpalmerah

Ariadi, H. (2005). Persepsi Pasien Terhadap Mutu Pelayanan Dokter Ditinjau Dari Karakteristik Dan Mutu Pelayanan Dokter Di Instalasi Rawat Jalan RSI Sunan Kudus Tahun 2005. Tesis. Magister Ilmu Kesehatan Masyarakat Universitas Diponegoro: Semarang.

Bakri. (2015). Kasus Pelemparan Dokter Hanya Miskomunikasi. Diakses pada Maret 2017, dari http://aceh.tribunnews.com/2015/08/ 23/ kasuspelemparan-dokter-hanyamiskomunikasi

Hartawan, T. (2014). Malpraktek, Pemilik Klinik Metropole Ditangkap. Diakses pada Januari, dari https://m.tempo.co/read/news/2014/1 0/04/064611957/ malpraktekpemilikklinik-metropole-ditangkap

Kompas. (2013). Komunikasi DokterPasien Belum Optimal. Diakses pada Maret 2017, dari http://tekno.kompas.com/read/2013/0 2/21/03001888/

komunikasi.dokterpasien. belum.optimal

Rmol. (2011). Komunikasi Gak Nyambung, Pasien Kerap Adukan Dokter. Diakses Pada Februari 2017, dari

http://ekbis.rmol.co/read/2011/07/01/ 31700/Komunikasi-Nggak-

Nyambung,-Pasien-Kerap-AdukanDokter-

Rusdianto. (2016). Pasien BPJS Ramairamai Mutasi ke Klinik. Diakses 
pada November 2016, dari http://kepri.antaranews.com/berita/36 457/pasienbpjs-ramai-ramai-mutasike-klinik.

Sari, P.C.P. (2013). Faktor-Faktor Yang Memperngaruhi Keputusan Berobat Serta

Dampaknya Terhadap Kepuasan Pasien. Fakultas Ekonomi dan Bisnis Universitas Diponegoro: Semarang.

Wigati, P.A. (2008). Analisis Pengaruh Persepsi Pasien Tentang Mutu Pelayanan Dokter Terhadap Loyalitas Pasien Di Poliklinik Umum Instalansi Rawat Jalan Rumah Sakit Panti Wilasa Citarum Semarang Tahun 2008.Universitas Diponegoro: Semarang. 